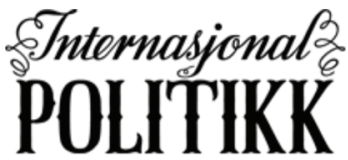

\section{Hvorfor så ambivalent? USAs politikk overfor EUs forsvarsambisjoner}

\author{
Bjørn Olav Knutsen \\ Kari Tvetbråten \\ Romerike revisjon IKS, Norge
}

Forsvarets forskningsinstitutt (FFI) E Nord universitet, Norge

\begin{abstract}
Sammendrag
Artikkelen diskuterer forholdet mellom den europeiske integrasjonsprosessen og det atlantiske samarbeidet under USAs ledelse. Problemstillingen artikkelen besvarer er hvilke tilnærminger Trump-administrasjonen har hatt til EUs sikkerhets- og forsvarspolitikk, og hvordan vi kan forklare denne tilnærmingen. I særlig grad dreier dette seg om balansegangen mellom europeisk strategisk autonomi på den ene siden, og amerikansk lederskap i Nato på den andre. Dette forholdet må forstås i lys av spørsmålet om lederskap i euroatlantisk sikkerhetspolitikk, noe som har vært et gjennomgangstema i europeisk integrasjon siden starten på 1950-tallet. Med en organisasjonsteoretisk tilnærming søker artikkelen å forklare hvorfor USA inntar et mer instrumentelt perspektiv overfor EU. Et slikt perspektiv innebærer at USA prioriterer ressurser til de områdene i verden der USA står overfor de største sikkerhetspolitiske utfordringene. For å forklare denne utviklingen diskuterer artikkelen USAs holdninger til EUs nyere forsvarsinitiativer og supermaktens ambivalens i forhold til disse. I møte med den nye Biden-administrasjonen blir det derfor viktig å avklare grunnlaget for det transatlantiske sikkerhetsfellesskapet. Et slikt fellesskap dreier seg ikke bare om felles interesser, men også om delte normer og verdier om hvordan en skal håndtere felles sikkerhetsutfordringer.
\end{abstract}

Nøkkelord: USA • EU • Nato • organisasjonsteori • sikkerhetspolitikk

\footnotetext{
^Kontaktinformasjon: Bjørn Olav Knutsen, e-post: bjorn-olav.knutsen@ffi.no 


\section{Innledning}

Transatlantiske relasjoner kan forstås som relasjonene mellom USA og Den europeiske union (EU), som igjen er en del av et bredere rammeverk av institusjoner der Nato er det viktigste fundamentet. Samlet utgjør dette det vestlige multilaterale systemet (Smith, 2018, s. 539). Disse relasjonene går utvilsomt gjennom store endringsprosesser. USA har foretatt en kursjustering av sin utenriks- og sikkerhetspolitikk i unilateralistisk retning (National Security Strategy, 2017). Supermakten nedtoner sin internasjonale ledervilje, og dermed støtten til kollektive løsninger, for håndteringen av internasjonale utfordringer (Melby, 2017, 2018). Den pågående korona-krisen akselererer prosessen ytterligere (Applebaum, 2020; Packer, 2020). Samtidig søker EU å styrke unionen som en selvstendig aktør i utenriks- og sikkerhetspolitikken. Slike utviklingstrekk vil også gjøre seg gjeldende når Joe Biden blir president i januar 2021 .

Alt dette er tegn på at USA og EU sakte glir fra hverandre (Howorth, 2018; Riddervold \& Newsome, 2018). Stadig negative utfall fra avtroppende president Donald J. Trumps side mot de europeiske allierte, som at Nato er overflødig, at brexit bidrar til at Storbritannia tar tilbake kontrollen fra EU og at Tyskland er gratispassasjer på det euroatlantiske samarbeidet, synes å bekrefte dette. Utover dette har konkrete handlinger som amerikansk uttreden av Paris-avtalen, tilbaketrekningen fra atomavtalen med Iran, utmeldelsen fra Verdens helseorganisasjon (WHO) og varselet om at USA trekker 9500 soldater fra Tyskland uten konsultasjoner med europeiske allierte, vist amerikansk unilateralisme i praksis. Det betyr en til dels betydelig mindre støtte til multilaterale løsninger på regionale og globale spørsmål (Binnendijk, 2020; Gordon, 2020; Stone, 2020; Tollefson, 2017). Selv om Joe Biden åpenbart vil prioritere institusjonalisert samarbeid i langt høyere grad enn president Trump, har de fire siste årene medført grunnleggende endringer i de transatlantiske relasjonene. Uten president Trump er det langt fra sikkert at EU hadde intensivert sitt sikkerhets- og forsvarspolitiske samarbeid. Dette er et samarbeid som ikke vil bli reversert selv om USA får en ny administrasjon (Barnes-Dacey et al., 2020).

Det betyr at det tradisjonelle grunnlaget for det transatlantiske sikkerhetsfellesskapet endres. Dette fellesskapet har lagt grunnlaget for fred og sikkerhet i det euroatlantiske området i etterkrigstiden, og i årene etter den kalde krigens bortfall (Adler \& Barnett, 1998; Deutsch et al., 1957; Howorth, 2014; Ikenberry, 2018). Dette aktualiserer spørsmålet om lederskap i euroatlantisk sikkerhetspolitikk, et spørsmål som har vært et gjennomgangstema i europeisk integrasjonspolitikk siden starten på 1950-tallet (Hoffmann, 1964; Howorth, 2014; Lundestad, 1997; Sæter, 1971, 2005).

\section{Formål og problemstilling}

Formålet med artikkelen er å undersøke om vi ser en forvitring av det transatlantiske fellesskapet, og å forstå de prosesser som foregår. Slik er artikkelen et bidrag til den stadig voksende forskningslitteraturen om Natos tilpasning til endrede 
rammebetingelser (Benitez, 2019; Kaufman, 2017; Peterson, 2018). Den bygger også på tidligere studier av utviklingen av EU som sikkerhets- og forsvarspolitisk aktør (Howorth, 2014; Riddervold \& Rosén, 2018; Sjursen, 2016; Smith, 2018; Tvetbråten \& Knutsen, 2019). Artikkelen trekker disse studiene videre ved å identifisere og forklare USAs tilnærming til EUs forsvarsambisjoner.

Problemstillingene vi svarer på er følgende: Hvilke tilnarminger har Trumpadministrasjonen hatt til EUs sikkerhets- og forsvarspolitikk? Hvordan kan vi forklare disse tilncermingene?

Artikkelen tar et organisasjonsteoretisk perspektiv der vi drar nytte av instrumentelle og institusjonelle perspektiver (Christensen et al., 2015). Slik er artikkelen annerledes enn øvrige bidrag som drar veksler på teorier fra internasjonal politikk. Et organisasjonsteoretisk perspektiv er nyttig for å kunne forklare og forstå aktørenes identiteter, interesser og handlemåter. Disse perspektivene er særlig relevante ettersom ingen regioner i verden er så tett sammenknyttet institusjonelt i økonomisk, politisk og sikkerhetspolitisk forstand som relasjonene mellom Europa og USA.

Artikkelen er organisert slik at vi i neste del ser nærmere på de to teoretiske innfallsvinklene, før vi undersøker USAs tilnærming til EUs initiativer til sikkerhets- og forsvarspolitisk integrasjon. Deretter analyserer vi hvordan de to teoretiske tilnærmingene forklarer det transatlantiske samarbeidet under nyere rammebetingelser. Til sist summerer vi opp diskusjonen, og peker på noen forhold som bør bli gjort til gjenstand for ny forskning på området.

\section{Instrumentelle og institusjonelle tilnærminger}

Den instrumentelle tilnærmingen legger til grunn at aktørene handler formålsrasjonelt. Det vil si at aktørene velger handlingsalternativer som mest sannsynlig bidrar til å nå deres målsettinger. Fire elementer kjennetegner en slik konsekvenslogikk (Christensen et al., 2015, s. 35). Det første er identifisering av et mål eller problem. Dette innebærer at aktørene definerer en målsetting, og vurderer avstanden til målet. Det andre er alternativer, og viser til at aktørene vurderer et sett av mulige handlinger. Det tredje er konsekvenser, og innebærer at aktørene vurderer forventede konsekvenser for hvert av alternativene. Det fjerde er beslutningsregler. Det viser til hvordan aktørene velger mellom alternativene.

Instrumentelle teorier skiller videre mellom fullstendig og begrenset rasjonalitet (Christensen et al., 2015, s. 36). Fullstendig rasjonalitet er oppfylt når en aktør eller organisasjon søker maksimering. Det vil si klare og konsistente mål, full oversikt over alternativer og sannsynlige konsekvenser, og deretter valg av det alternativet som gir størst forventet måloppnåelse. Begrenset rasjonalitet er oppfylt når en aktør eller organisasjon velger tilfredsstillende løsninger. Denne retningen tar hensyn til at fullstendig rasjonalitet kan stille høyere krav enn aktører og organisasjoner har kapasitet til å håndtere. En organisasjon kan for eksempel ha uklare, inkonsistente og ustabile målsettinger, komplekse problemer og ufullstendig informasjon om alternativer og 
konsekvenser. Det kan derfor være mer realistisk å forvente at aktører og organisasjoner velger en løsning som er god nok.

Trump-administrasjonen uttrykker en målsetting om å opprettholde et amerikansk sikkerhetspolitisk lederskap (National Security Strategy, 2017). Et instrumentelt perspektiv forventer dermed at Trump-administrasjonen til enhver tid prioriterer amerikanske ressurser til områder i verden der USA står overfor de største sikkerhetspolitiske utfordringene. I tråd med en slik konsekvenslogikk vil dermed valget mellom bilateralt og flernasjonalt samarbeid avhenge av situasjonen. Det sentrale er hvorvidt Trump-administrasjonens handlinger samsvarer med en konsekvenslogikk der valg mellom mulige alternativer bygger på rasjonelle kalkulasjoner om mulige konsekvenser. Utfordringen her er at president Trump har vært den mest kaotiske presidenten i amerikansk historie. Ingen amerikansk president har vist seg så villig til å stole på instinktene heller enn forsiktig analyse og institusjonaliserte beslutningsprosesser. Vi må derfor inkludere enkeltpersoners betydning når vi studerer utenrikspolitiske utfall (Byman \& Pollack, 2001, s. 135). Trumps syn kommer da også til syne i den nasjonale sikkerhetsstrategien (2017), som har en nokså transaksjonell tilnærming til hvordan USA skal opptre i forhold til andre stater.

Institusjonelle teorier legger på sin side til grunn at organisasjoner har egne institusjonelle regler, verdier og normer, og at de påvirker aktørenes beslutninger (Christensen et al., 2015, s. 13-14). Kulturperspektivet er en retning innenfor institusjonelle teorier som vektlegger betydningen av organisasjonskultur. Dette kan være uformelle normer og verdier som utvikler seg over tid. Aktørene tar dermed ikke bare hensyn til fremtidige konsekvenser, men også til løsninger som tidligere har fungert godt. Kulturperspektivet legger videre til grunn at aktørene søker å legitimere sine handlinger. Det vil si at aktørene velger handlingsalternativer som andre oppfatter som rettmessige og rettferdige, altså etter en logikk om det kulturelt passende (Christensen et al., 2015, s. 52-54). Denne logikken bygger på tre elementer. Det første viser til gjenkjennelse, altså en situasjon som er typisk og rutinepreget. Det andre er identitet, det vil si en vurdering av hvilke identiteter som er viktigst for aktøren og institusjonen. Det tredje er handlingsregler, der valg i en gitt situasjon samsvarer med organisasjonens kultur.

Et kulturperspektiv forventer at Trump-administrasjonen handler tradisjonelt, altså at den vektlegger løsninger som samsvarer med etablert kultur. Dermed forventer vi at Trump-administrasjonen prioriterer transatlantisk samarbeid under amerikansk ledelse der europeisk integrasjon foregår innenfor atlantiske rammer. Endringer i omgivelsene påvirker dermed administrasjonen i liten grad.

\section{USA og den europeiske forsvarspakken}

Grunnlaget for EUs forsvarspakke

Som vi ser har begge tilnærminger forventninger om at USA søker å opprettholde sitt sikkerhetspolitiske lederskap i Europa. Utfordringen er om USA i fortsettelsen 
ønsker å opprettholde et slikt lederskap, som er basert på de premissene som tradisjonelt har ligget til grunn for det euroatlantiske sikkerhetsfelleskapet. Det har blant annet vært premisser knyttet til multilateralisme, og Nato som det fremste institusjonelle rammeverket for transatlantiske konsultasjoner i sikkerhetsspørsmål. Innenfor forskning om sikkerhetsfellesskap taler en i denne sammenhengen om delte identiteter, verdier og meninger, som da vil være grunnlaget for fortsatt opprettholdelse av et slikt fellesskap (Adler \& Barnett, 1998, s. 31).

Uansett er det slik at den storpolitiske utviklingen i lang tid allerede har tildelt Europa en mer sekundær rolle i amerikansk utenrikspolitikk (se for eksempel McKay, 2019; Melby, 2005, s. 30-31). I dag vokser Kina frem som den virkelig store utfordreren til USAs globale maktposisjon (Tunsjø, 2018), noe Trumpadministrasjonens sikkerhetsstrategi (2017) understreker flere steder. Samtidig illustrerer Trump-administrasjonens holdninger til EUs sikkerhets- og forsvarspolitiske samarbeid (CSDP) en opptrapping av lederskapskonflikten i euroatlantisk sikkerhetspolitikk. Dette kommer til uttrykk i form av at president Trump er den første amerikanske presidenten som uttrykker skepsis mot EU, og som endog har omtalt unionen som en fiende av USA i handelspolitiske spørsmål (Roth et al., 2018). Dette gjelder ikke bare presidenten - også hans utenriksminister, Mike Pompeo, har ved flere anledninger uttrykt skepsis mot EU og andre multilaterale sammenslutninger (Speck, 2018).

Denne lederskapskonflikten er uløselig knyttet til EUs forhold til Nato og om den USA-dominerte alliansen skal sette rammer for hvor langt integrasjonsprosessen skal gå på det sikkerhets- og forsvarspolitiske området. Den langsiktige problemstillingen blir derfor hvor mye innflytelse EU og de europeiske medlemsstatene skal ha i Nato. Hele spørsmålet om amerikansk ambivalens til EUs forsvarsambisjoner dreier seg derfor om balansegangen mellom europeisk strategisk autonomi på den ene siden, og amerikansk lederskap i Nato på den andre. Denne lederskapskonflikten vil ikke forsvinne med Joe Biden som president, siden dette grunnleggende sett dreier seg om de maktpolitiske forholdene mellom USA og EU-prosessens videre utvikling.

Dette danner grunnlaget for å forklare hvorfor EU lanserte forsvarspakken. Lenge ble det som Lisboa-traktaten omtaler som permanent strukturert samarbeid (PESCO) betraktet som politisk umulig å få til. Den russiske annekteringen av Krim-halvøya (2014), den britiske beslutningen om å tre ut av EU (brexit) (2016) og valget av Donald J. Trump til USAs president (2016), var det som til sammen bidro til snuoperasjonen (Biscop, 2017, s. 3).

Foruten PESCO omfatter forsvarspakken Coordinated Annual Review on Defence (CARD) og det europeiske forsvarsfondet (EDF). Pakken må forstås som en helhet. CARD skal identifisere kapabilitetsmangler, bidra til forsterket forsvarssamarbeid, og dermed en mer optimal anvendelse av forsvarsressursene. Slik skal CARD legge grunnlag for kapabilitetsprosjekter som kommer til uttrykk i PESCO. Målet er at CARD vil bidra til en gradvis synkronisering og gjensidig tilpasning av nasjonale forsvarsplanleggingssykluser og kapabilitetsutviklingspraksiser (EDA, 2017; EEAS, 
2017). CARD og EDF er i motsetning til PESCO ikke traktatfestet. PESCO er kapabilitetsdrevet, og skal gjennom et sett med forpliktende prosjekter bidra til bedringer i EUs operative evne (Notification on Permanent Structured Cooperation, 2017). Alle 25 deltakerstater i PESCO skal delta i minst ett PESCO-prosjekt som skal ha strategisk effekt. Disse kommer til uttrykk i form av forpliktelser til økninger i forsvarsbudsjettene og økninger i midlene til forsvarsforskning. Hensikten er å etablere flere samarbeidsprosjekter som samlet skal bidra til at EU når sine ambisjonsnivåer. Disse overordnede ambisjonsnivåene ble fastslått så tidlig som i 1999 i form av de såkalte Helsinki Headline Goals, og oppdatert i 2004 (EU, 1999, 2004). Dette ambisjonsnivåt innebærer at EU skal være i stand til å generere en militær styrke på i alt 60000 soldater innen 60 dager til et operasjonsområde. Tilsvarende sivile Headline Goals har også blitt etablert.

Alt dette vil ikke være mulig uten det europeiske forsvarsfondet. EDF skal således støtte medlemsstatene i utviklingen av forsvarsmateriell og teknologi. Målet er å styrke den europeiske forsvarsindustrielle teknologibasen slik at EU ikke skal giøre seg for avhengig av utenforstående aktører i utviklingen av teknologisk avansert forsvarsmateriell (Biscop, 2018). To tredeler av fondet er satt av til kapabilitetsprogrammer, mens den siste tredelen skal finansiere europeisk forsvarsforskning. I henhold til forordningen som etablerer EDF kan fondet for PESCO-prosjekters del finansiere opptil 30 prosent av utviklingskostnadene (Europakommisjonen, 2018). For øvrige prosjekter er bidraget inntil 20 prosent. Størrelsesmessig ligger fondet an til å bli rundt 7 milliarder euro over budsjettperioden 2021 til 2027.

Målet med forsvarspakken er å sikre EU strategisk autonomi. Det innebærer at EU blir i stand til å handle, helst sammen med partnere som Nato og USA, men om nødvendig også alene i militære operasjoner (Tvetbråten \& Knutsen, 2019, s. 399; se også EU, 2016; Fiott, 2018). Slik skal EU bli i stand til å opptre strategisk, noe som igjen betyr at EU ikke bare skal være en tilskuer, men også en aktør på den internasjonale arenaen (Biscop, 2019).

Trump-administrasjonens holdninger og handlinger

Det er åpenbart at forsvarspakken berører fundamentale amerikanske interesser i Europa. Den omtalte lederskapskonflikten danner grunnlaget for å forstå USAs holdninger og handlinger til EUs forsvarspakke. USAs mål er at europeisk integrasjon foregår innenfor USA-dominerte atlantiske rammebetingelser (Howorth, 2018). Det betyr for alle praktiske formål Nato-rammen, selv om president Trump og hans administrasion ved flere anledninger har uttrykt skepsis mot Nato og sine europeiske allierte (se for eksempel Bolton, 2020, s. 140; Herszenhorn, 2020). Den grunnleggende betingelsen fra amerikansk side er at EUs forsvarsambisjoner ikke må utfordre Nato, og dermed grunnlaget og legitimiteten for USAs tilstedeværelse i Europa. Siden USA alltid har vært den dominerende parten i Nato, har alliansen bidratt til at de europeiske allierte forblir underordnet amerikansk sikkerhetspolitisk lederskap (Posen, 2014; Menon \& Ruger, 2020, s. 372). 
Likevel, den nasjonale sikkerhetsstrategien omtaler EU bare én gang i det 55 sider lange dokumentet (National Security Strategy, 2017, s. 25). Selv om en alltid kan diskutere den reelle nytteverdien av slike strategier, er det likevel et uttrykk for USAs fallende interesse for europeisk sikkerhetspolitikk. Dette var også årsaken til at CSDP i sin tid ble etablert (Howorth, 2014, s. 110-117). Vi ser dermed en utvikling der amerikanerne krever at de europeiske allierte tar et større ansvar for egen sikkerhet i nærområdene. Dette kommer til uttrykk i byrdefordelingsdebatten, som ble forsterket under Obama-administrasjonen og virkelig satt på spissen under president Trump. Biden-administrasjonen må derfor søke å dra fordeler av sitt største fortrinn sammenlignet med Kina og Russland, nemlig et globalt alliansesystem. Dette er et system den utgående Trump-administrasjonen åpenbart har undervurdert betydningen av. Å bidra til å reformere eksisterende institusjoner, som Nato, vil derfor måtte danne et nytt grunnlag for amerikansk utenrikspolitikk. Et slikt allianse- og institusjonssystem danner en viktig styrkemultiplikator for amerikansk makt (Jensen \& Packard, 2020). Det betyr mer støtte til at europeerne tar et større ansvar for egen sikkerhet, men det betyr også at den amerikanske støtten til EUs forsvarsambisjoner ikke er ubetinget. EUs ambisjoner må ikke utfordre Nato, og dermed grunnlaget for USAs politiske og militære tilstedeværelse i Europa.

Dette kommer til uttrykk på to plan, hvorav det første er forholdet mellom EU og Nato. Trump- og den kommende Biden-administrasjonen ønsker et tettest mulig samarbeid mellom de to institusjonene. Slik sett ser vi en videreføring av USAs holdninger sammenlignet med den foregående Obama-administrasjonen. I felleserklæringen mellom EU og Nato, som ble undertegnet under Nato-toppmøtet i Warszawa i 2016, inngikk de to institusjonene en omfattende samarbeidsavtale (Nato, 2016). Flere saksområder danner grunnlaget for samarbeidet, herunder samarbeid om cyber-utfordringer og hybrid krigføring. Felles øvelser for å håndtere sikkerhetsutfordringer blir også gjennomført. Samarbeidet mellom de to skal da også være basert på prinsippene om samhørighet (coherence), kompabilitet (compability) og gjennomsiktighet (transparency). Denne formen for samarbeid har blitt videreført under Trump-administrasjonen.

Det andre, som er minst like viktig, er spørsmålet om tredjelandsdeltakelse i PESCO og EDF. Frykten for europeisk proteksjonisme gjør at amerikanerne ser for seg at amerikansk forsvarsindustri vil miste markedsandeler i Europa. I en mye omtalt brevveksling mellom Pentagon, det amerikanske utenriksdepartementet og EU fra mai 2019 uttrykte amerikanerne «dyp bekymring» over EUs ambisjoner fordi dette vil kunne frata amerikansk forsvarsindustri tilstrekkelig tilgang til det europeiske forsvarsmarkedet (McLeary, 2019). Selv om amerikanerne på et overordnet plan uttrykte støtte til EUs planer, mente de at flere av de foreslåtte tiltakene utgjorde en "giftpille» mot transatlantisk samarbeid og utviklingen av det transatlantiske forsvarsmarkedet. Det er i særlig grad EDF amerikanerne er skeptiske til, som blir omtalt som proteksjonistisk overfor tredjeland (Fiott, 2019). Dessuten reagerer 
USA på at Europakommisjonen vil sikre at såkalte intellektuelle eiendomsrettigheter (IPR) innenfor forsvarsteknologi skal forbli innenfor EU.

Samtidig utøver USA en proteksjonistisk politikk selv i form av Buy American Act og International Traffic in Arms Regulation (ITAR). Spesielt ITAR-regelverket er en utfordring for de europeiske allierte, som ilegges begrensninger på bruk av amerikansk forsvarsmateriell og endog for videresalg av forsvarsmateriell mellom seg (Fiott, 2019). Dette vil ha som konsekvens at USA er i stand til å styre europeiske operasjoner og således begrense EUs mål om strategisk autonomi. Utover dette er det europeiske forsvarsmarkedet langt mer åpent enn det amerikanske.

Likevel mener USA at USA-baserte selskaper, både de som er lokalisert i USA og i EU, skal kunne delta i EU-finansierte kapabilitetsprosjekter og forsvarsforskingsprogrammer (AmCham EU, 2019). Utfordringen er at USA står utenfor det indre markedet og tollunionen, noe som automatisk innebærer at utenforstående aktører blir utelukket. Dette gjelder imidlertid ikke for Norge som gis mulighet til å delta i EDF på grunn av EØS-avtalen (Prop. 62S 2019-2020, s. 81). Det tyske EUformannskapet arbeidet høsten 2020 med betingelsene for tredjelandsdeltakelse i forsvarspakken. Resultatet ble at amerikanerne nå, under visse betingelser, kan delta i både EDF og PESCO (Council Decision, 27. okober 2020). Når det gjelder PESCO vil amerikanerne prioritere prosjektet «militær mobilitet». Andre prosjekter kan også være aktuelle. Under EDF vil de kunne delta på samme måte som under forløperen til forsvarsfondet, nemlig European defence industrial development programme (EDIDP).

Fra et overordnet plan, må USAs holdninger overfor EUs forsvarspakke vurderes i relasjon til hvordan USA posisjonerer seg overfor Kina. I denne situasjonen vil det være slik at å ha europeiske allierte i den tiltakende rivaliseringen, åpenbart vil være i amerikansk interesse. Fra amerikansk hold vurderes det derfor dit hen at jo tettere EU-Nato samarbeidet blir, og jo mer USA kan bli involvert i EUs forsvarspakke, i desto sterkere grad vil de europeiske allierte bli knyttet til USAs globale aspirasjoner der forholdet til Kina er dominerende (Brattberg, 2019). Dette vil imidlertid ikke nødvendigvis være i europeisk interesse, siden et integrert EU på det sikkerhets- og forsvarspolitiske området øker behovet for EU-selvstendighet. I en slik situasjon må de europeiske allierte posisjonere seg slik at de ikke bare blir brikker i det storpolitiske spillet mellom de to supermaktene. I tillegg viser John Boltons bok (2020, s. 70-71) hvordan president Trump var opprørt over Tysklands avhengighet av Russland for import av naturgass. Dette er en utfordring som vil vedvare under den kommende amerikanske administrasjonen.

Vi får derfor en tiltakende debatt om muligheten for et globalt Nato, som da både vil måtte håndtere den kinesiske og den russiske utfordringen. En slik debatt vil imidlertid anta en litt annen karakter enn den som rådde i perioden 2001 til 2006, da noen av de samme problemstillingene ble diskutert (se for eksempel Cox, 2005; Daalder \& Goldgeier, 2006). Følgelig blir spørsmålet om Nato skal bli et globalt intervensjonsinstrument under amerikansk ledelse. I et slikt tilfelle vil EU 
kunne bli en sterkere sikkerhetspolitisk aktør, men da bare innenfor USA-definerte rammer.

\section{Transatlantisk sikkerhetspolitisk samarbeid under nye rammebetingelser}

Analysen i forrige avsnitt viser at det tradisjonelle transatlantiske sikkerhetsfellesskapet går gjennom dyptgripende endringer. Det er imidlertid for tidlig å si i hvor stor grad fellesskapet forvitrer. Samtidig må vi unngå det Michael Cox hevdet under den forrige transatlantiske krisen som ble utløst av Irak-krigen, nemlig intellektuell selvtilfredshet» (Cox, 2005, s. 205). Det betyr at man skal vokte seg vel for å anta at forholdet mellom USA og Europa vil rette seg bare USA får en ny administrasion. Det blir dermed riktigere å betrakte Trump-administrasjonen som et symptom på at vi står overfor et endret USA med et nytt syn på seg selv og sin rolle i verden (Melby, 2017). Dette inkluderer Kina som en ny og dimensjonerende hovedutfordrer. Slik ser vi at Trump-administrasjonen har markert en helt annen tilnærming til det euroatlantiske samarbeidet enn tidligere administrasjoner. Dette kommer til uttrykk gjennom en "kompetitiv tilnærming» til internasjonal politikk med en nedtoning av institusjonsbasert samarbeid. Det er liten tvil om at en slik tilnærming er uforenlig med opprettholdelsen av et transatlantisk sikkerhetsfellesskap. Å betrakte internasjonal politikk som en "sivilisasjonskamp» (Restad, 2020, s. 27), bidrar dermed utvilsomt til å utfordre de grunnleggende prinsippene og fundamentene for dette felleskapet (Adler \& Barnett, 1998, s. 30-37).

Dermed ser vi at USA ikke i så stor grad vektlegger løsninger som samsvarer med etablert kultur i form av de identitetene, normene og verdiene som har grunnlagt felleskapet. Det betyr at USA i mindre grad opptrer i henhold til en logikk om det kulturelt passende. Konsekvensene blir at de europeiske allierte, i første rekke gjennom EU, må ta et større ansvar for egen sikkerhet. Dermed aktualiseres en av de store stridstemaene i europeisk integrasjonspolitikk, nemlig balansegangen mellom europeisk strategisk autonomi og amerikansk lederskap. I dette perspektivet nytter det heller ikke, som enkelte giør (se for eksempel Van Ham, 2018, s. 13), å vise til at USA tross alt har styrket sin militære tilstedeværelse i Europa de seneste årene. Her har argumentene vært at handlinger teller mer enn ord og holdninger. Så lenge disse militære enhetene ikke blir knyttet til en kollektivisert europeisk sikkerhetsordning, vil ikke økt militær tilstedeværelse nødvendigvis bidra nevneverdig til europeisk sikkerhet.

Eksempelvis viser den plutselige beslutningen om å trekke 9500 soldater fra Tyskland nok en gang hvor svekket de transatlantiske konsultasjonsmekanismene er (Binnendijk, 2020; Gordon, 2020). Fra et analytisk ståsted illustrerer dette at det vi har omtalt som en institusjonell tilnærming i mindre grad er relevant for å studere transatlantiske relasjoner. I særlig grad gjelder dette kulturperspektivet der aktørene søker å legitimere sine handlinger. En svekkelse av konsultasjonsmekanismene er dermed et tegn på en svekkelse av de handlingsreglene som har ligget til grunn for samarbeidet i Nato. 
En mer instrumentell tilnærming til europeisk sikkerhet vokser dermed frem. Samtidig må vi huske på at det fremdeles er sterk støtte i USA til at landet utøver et stort internasjonalt engasjement, selv om konsensusen om hvordan dette utøves, er svekket (Restad, 2019, s. 91-92). Utfordringen så langt er at EU fortsatt er avhengig av Nato, og dermed USA, for det kollektive forsvaret. Dette forklarer hvorfor USA, til tross for stadig gjentatte krav om en bedre byrdefordeling i Nato (se Nato, 2014), aldri har krevd at EU etablerer en autonom forsvarsevne (Menon \& Ruger, 2020, s. 372). Dette er også årsaken til at president Trumps sikkerhetsstrategi (2017) inneholder mange positive referanser til Nato og at USA forblir forpliktet til sine europeiske allierte. Derfor er Nato-alliansen «av frie og selvstendige stater» en stor fordel for USA sammenliknet med konkurrentene på den internasjonale arenaen (National Security Strategy, 2017, s. 48).

Dermed står vi overfor et USA som gjennom en instrumentell tilnærming til enhver tid vil prioritere ressurser til områder i verden der de står overfor de største sikkerhetsutfordringene. Mindre og mellomstore europeiske medlemsstater i EU og Nato vil være ekstra sårbare i en slik situasjon. Det grunnleggende spørsmålet er om de europeiske medlemmene av EU og Nato vil være i stand til å ta et større ansvar for egen sikkerhet. Denne har for alle praktiske formål vært delegert til amerikanerne i mer enn syv tiår. Utfordringen blir å bygge det som blir omtalt som motstandsdyktighet (《resiliens»). Dette har blitt mer aktuelt som følge av de komplekse sett av utfordringer de europeiske allierte står overfor, og som også korona-krisen har illustrert. Derfor blir de europeiske forsvarsinitiativene viktige for å bygge motstandsdyktighet gjennom å betrakte indre og ytre sikkerhet i en større sammenheng.

En av konsekvensene er at EU for tiden arbeider med det de omtaler som et «strategisk kompass». Målet med et slikt kompass er å styrke den felleseuropeiske evnen til å handle hurtig i tilfelle en krise. Dette krever en form for europeisk strategisk kultur som kan bringe nasjonale perspektiver på sikkerhetsutfordringene nærmere hverandre (Gouvernement, 2020). Dette blir i så fall i en situasjon der det tradisjonelle amerikanske lederskapet er av en helt annen karakter enn tidligere.

\section{Avslutning}

I denne artikkelen har vi med bakgrunn i instrumentelle og institusjonelle tilnærminger undersøkt Trump-administrasjonens politikk overfor EUs forsvarsinitiativer. En mer instrumentell og endog kompetitiv tilnærming til internasjonal politikk utviklet seg, som åpenbart har hatt konsekvenser for det euroatlantiske sikkerhetsfellesskapet. Det forhold at Donald Trump var en kaotisk og uforutsigbar president påvirket også de transatlantiske relasjonene. Utfordringen for Biden-administrasjonen og de europeiske partnerne er å reetablere dette fellesskapet på delvis nytt grunnlag. Den omtalte lederskapskonflikten vil imidlertid fortsatt gjøre seg gjeldende under president Biden, selv om han åpenbart vil satse på en mer institusjonell tilnærming. Uansett blir det enkelte forskere mener feil. Det er ikke nødvendigvis slik at det 
alltid vil være et sikkerhetsfellesskap mellom USA og EU, bare de makter å løse sine uenigheter på en fredelig måte (Cox, 2005; Pouliot, 2006).

Forsterket EU-integrasjon på det sikkerhets- og forsvarspolitiske området vil automatisk innebære større autonomi. I tilfelle uenighet mellom USA og EU er det godt mulig at EU og medlemsstatene vil iverksette tiltak som faller inn under kategorien «myk balansering» (Pape, 2006). Dette kan være på områder der de europeiske partnerne er uenig med USA, slik som atomavtalen med Iran og import av naturgass fra Russland.

Uansett er det viktig å utvikle et omforent teoretisk rammeverk som kan forklare hva det er som bidrar til endring og endog forvitring av årtier lange sikkerhetsfellesskap. Dette vil spesielt være sikkerhetsfelleskap der partene har delte, ikke bare felles, interesser, men også institusjoner, normer og verdier om hvordan en skal håndtere felles sikkerhetsutfordringer.

\section{Om forfatterne}

Bjørn Olav Knutsen har hovedfag i statsvitenskap fra Universitetet i Oslo (UiO). Han er i dag sjefsforsker ved Forsvarets forskningsinstitutt (FFI) og førsteamanuensis i statsvitenskap ved Nord universitet i Bodø.

Kari Tvetbråten har mastergrad i statsvitenskap fra Universitetet i Oslo (UiO) med spesialisering innenfor offentlig politikk og administrasjon. Hun har over ti års erfaring som forsker ved Forsvarets forskningsinstitutt (FFI) og arbeider i dag som senior forvaltningsrevisor ved Romerike revisjon IKS.

\section{Referanser}

Adler, E. \& Barnett, M. (1998). A framework for the study of security communities. I E. Adler \& M. Barnett (Red.), Security communities (s. 29-65). Cambridge University Press.

AmCham. (2019). The European defence action plan. Challenges and perspectives for a genuine transatlantic defence and industrial relationship. https:/www.amchameu.eu/system/files/position_papers/final_website_edap_ with_recommendations.pdf

Applebaum, A. (2020). History will judge the complicit. Why have Republican leaders abandoned their principles in support of an immoral and dangerous president? The Atlantic. https://www.theatlantic.com/ magazine/archive/2020/07/trumps-collaborators/612250/

Barnes-Dacey, J., Dennison, S., Dworkin, A., Geranmayeh, E., Leonard, M., Murphy, T., Oertel, J., Popescu, N. \& Varma, T. (2020). A new transatlantic bargain: An action plan for transformation, not restoration. European Council on Foreign Relations (ECFR). https://ecfr.eu/wp-content/uploads/A-new-transatlantic-bargainAn-action-plan-for-transformation-not-restoration.pdf

Benitez, J. (2019). U.S. NATO policy in the age of Trump: Controversy and consistency. Fletcher Forum of World Affairs, 43(1), 179-200. https://static1.squarespace.com/static/579fc2ad725e253a86230610/t/5c6184e01 04c7bb62a1ed2eb/1549894881133/43_1+Benitez.pdf

Binnendijk, H. (2020, 9. juni). The folly of a NATO troop withdrawal decision. Defense Nerws. https://www. defensenews.com/opinion/commentary/2020/06/09/the-folly-of-a-nato-troop-withdrawal-decision/

Biscop, S. (2017). Oratio pro PESCO. Egmont paper 91. http://www.egmontinstitute.be/content/uploads/2017/ 01/ep91.pdf?type $=$ pdf

Biscop, S. (2018). European defence: Give PESCO a chance. Survival, 60(3), 161-180. https://www.tandfonline. com/doi/full/10.1080/00396338.2018.1470771 


\section{Bjørn Olav Knutsen og Kari Tvetbråten}

Biscop, S. (2019). European strategy in the $21^{\text {st }}$ century. Routledge.

Bolton, J. (2020). The room where it happened. A White House memoir. Simon \& Schuster.

Brattberg, E. (2019). Time for NATO to talk about China. Carnegie Europe. https://carnegieeurope.eu/ strategiceurope/78684

Byman, D. L. \& Pollack, K. M. (2001). Let us now praise great men: Bringing the statesman back in. International Security, 25(4), 107-146. https://www.jstor.org/stable/3092135?seq=1

Christensen,T., Egeberg, M. P. G. \& Røvik, K. A. (2015). Organisasjonsteorifor offentlig sektor. Universitetsforlaget.

Council Decision. (2020, 27. oktober). COUNCIL DECISION establishing the general conditions under which third States could exceptionally be invited to participate in individual PESCO projects. https://www.consilium. europa.eu/en/press/press-releases/2020/11/05/eu-defence-cooperation-council-sets-conditions-for-thirdstate-participation-in-pesco-projects/

Cox, M. (2005). Beyond the West: Terrors in Transatlantia. European fournal of International Relations, 11(2), 203-233. https://journals.sagepub.com/doi/pdf/10.1177/1354066105052964

Daalder, I. H. \& Goldgeier, J. (2006). Global NATO. Foreign Affairs. https://www.foreignaffairs.com/articles/ 2006-09-01/global-nato

Deutsch, K. (1957). Political community in the North Atlantic area. International organization in the light of historical experience. Princeton University Press.

EDA. (2017). Coordinated annual review on defence. https:/www.eda.europa.eu/what-we-do/our-currentpriorities/coordinated-annual-review-on-defence-(card)

EEAS. (2017). Coordinated annual review on defence. https://eeas.europa.eu/sites/eeas/files/coordinated_annual_ review_on_defence_card_factsheet.pdf

EU. (1999). Presidency conclusions Helsinki European Council. https://www.consilium.europa.eu/media/ 21046/helsinki-european-council-presidency-conclusions.pdf

EU. (2004, 19. juli). Presidency conclusions. http://data.consilium.europa.eu/doc/document/ST-10679-2004$\mathrm{REV}-2 / \mathrm{en} / \mathrm{pdf}$

EU (2016). Shared vision, common action: A stronger Europe. https://eeas.europa.eu/topics/eu-globalstrategy/17304/global-strategy-european-unions-foreign-and-security-policy_en

Europakommisjonen. (2018). Proposal for a regulation of the European Parliament and of the Council establishing the European Defence Fund. https://ec.europa.eu/commission/sites/beta-political/files/budget-may2018-eudefence-fund-regulation_en.pdf

Fiott, D. (2018). EU defence capability development. Plans. Priorites, projects. Brief Issue. EUISS. https://www.iss. europa.eu/content/eu-defence-capability-development---plans-priorities-projects

Fiott, D. (2019). The poison pill. EU defence on US terms? Brief, 7, juni 2019. https://www.iss.europa.eu/sites/ default/files/EUISSFiles/7\%20US-EU\%20defence\%20industries.pdf

Gordon, P. H. (2020, 8. juni). Trump's sudden and dangerous troop withdrawal from Germany. Council on Foreign Relations. https:/www.cfr.org/in-brief/trumps-sudden-and-dangerous-troop-withdrawal-germany

Gouvernement. (2020, 29. mai). At the heart of our European Union. https://www.gouvernement.fr/en/at-theheart-of-our-european-union

Herszenhorn, D. M. (2020, 29. juni). Trump's Europe strategy: Nothing. Politico. https://www.politico.eu/ article/donald-trump-eu-strategy-nothing-g7-summit-angela-merkel/

Hoffmann, S. (1964). De Gaulle, Europe, and the Atlantic Alliance. International Organization, 18(1), 1-28. https:/www.cambridge.org/core/journals/international-organization/article/de-gaulle-europe-and-theatlantic-alliance/36E34957EE2F3D7FE2C4F8AA63E76B75

Howorth, J. (2014). Security and defence in the European Union (EU). Palgrave Macmillan.

Howorth, J. (2018). Strategic autonomy and EU-NATO cooperation: Threat or opportunity for transatlantic defence relations? Fournal of European Integration, 40(5), 523-537. https://doi.org/10.1080/07036337.20 18.1512268

Ikenberry, G. J. (2018). The end of liberal international order? International Affairs, 94(1), 7-23. https://doi. org/10.1093/ia/iix241

Jensen, B. \& Packard, N. (2020, 30. november). The next national defense strategy. War on the Rocks. https:// warontherocks.com/2020/11/the-next-national-defense-strategy/

Kaufman, J. P. (2017). The US perspective on NATO under Trump: Lessons of the past and prospects for the future. International Affairs, 93(2), 251-266. https://doi.org/10.1093/ia/iix009

Lundestad, G. (1997). «Empire» by integration. The United States and European integration, 1945-1997. Oxford University Press. 
McKay, J. (2019). How transatlantic is the Trump administration? Fournal of Transatlantic Studies, 17, 532-553. https:/link.springer.com/article/10.1057/s42738-019-00030-0

McLeary, P. (2019, 19. mai). State, DoD letter warns European Union to open defense contracts, or else. Breaking Defense. https://breakingdefense.com/2019/05/state-dod-letter-warns-european-union-to-opendefense-contracts-or-else/

Melby, S. (2005). Europa sett i fra USA. I J. K. Skogan (Red.), Hva nå USA og Europa? (s. 15-31). Gyldendal.

Melby, S. (2017). USAs ledervilje svekkes. Maktpolitiske utfordringer og nye nasjonale forutsetninger. Fagbokforlaget.

Melby, S. (2018). Trumps nasjonale sikkerhetsstrategi. Ukens analyse, Den norske Atlanterhavskomité. https:// www.atlanterhavskomiteen.no/post/15463653/trumps-nasjonale-sikkerhetsstrategi

Menon, R. \& Ruger, W. (2020). NATO enlargement and US grand strategy: A net assessment. International Politics, 57, 371-400. https://doi.org/10.1057/s41311-020-00235-7

National Security Strategy of the United States of America. (2017). White House. https://www.whitehouse.gov/ articles/new-national-security-strategy-new-era/

Nato. (2014). Wales summit declaration. https://www.nato.int/cps/en/natohq/official_texts_112964.htm

Nato. (2016). Warsaw summit communiqué. https://www.nato.int/cps/en/natohq/official_texts_133169.htm

Notification on Permanent Structured Cooperation. (2017). https://www.consilium.europa.eu/media/31511/ 171113-pesco-notification.pdf

Packer, G. (2020). We are living in a failed state. The coronavirus didn't break America. It revealed what was already broken. The Atlantic. https://www.theatlantic.com/magazine/archive/2020/06/underlyingconditions/610261/

Pape, R. A. (2006). Soft balancing against the United States. International Security, 30(1), 7-45. https://doi. org/10.1162/0162288054894607

Posen, B. (2014). Restraint: A new foundation for U.S. grand strategy. Cornell University Press.

Pouliot, V. (2006). The alive and well transatlantic security community: A theoretical reply to Michael Cox. European Fournal of International Relations, 12(1), 119-127. https://doi.org/10.1177/1354066106061332

Prop 62 S (2019-2020). Viljetilberedskap-evnetilforsvar-Langtidsplanforforsvarssektoren. Forsvarsdepartementet. https://www.regjeringen.no/no/dokumenter/prop.-62-s-20192020/id2697623/

Restad, H. E. (2019). Whither the 'city upon a hill'? Donald Trump, America first, and American exceptionalism. Texas National Security Review, 3(1), 62-92. https://nsr.org/2019/12/whither-the-city-upon-a-hilldonald-trump-america-first-and-american-exceptionalism/

Restad, H. E. (2020). What makes America great? Donald Trump, national identity, and U.S. foreign policy. Global Affairs, 6(1), 21-36. https://doi.org/10.1080/23340460.2020.1734955

Riddervold, M. \& Newsome, A. (2018). Transatlantic relations in times of uncertainty: Crises and EU - US relations. Fournal of Transatlantic Relations, 40(5), 505-521. https://doi.org/10.1080/07036337.2018.148 8839

Riddervold, M. \& Rosén, G. (2018). Unified in response to rising powers? China, Russia and EU-US relations. Fournal of European Integration, 40(5), 555-570. https://doi.org/10.1080/07036337.2018.1488838

Roth, A., Smith, D., Helmore, E. \& Pengelly, M. (2018, 18. juli). Trump calls European Union a 'foe' - ahead of Russia and China. The Guardian. https://www.theguardian.com/us-news/2018/jul/15/donald-trumpvladimir-putin-helsinki-russia-indictments

Sjursen, H. (2016). Integrasjon uten føderasjon: EUs utenriks- og sikkerhetspolitikk. Norsk statsvitenskapelig tidsskrift, 32(4), 320-342. https://doi.org/10.18261/issn.1504-2936-2016-04-02

Smith, M. E. (2018). The EU, the US and the crisis of contemporary multilateralism. Fournal of European Integration, 40(5), 539-553. https://doi.org/10.1080/07036337.2018.1488836

Speck, U. (2018). For Europeans, Pompeo's speech in Brussels is a missed opportunity. The German Marshall Fund of the United States. https://www.gmfus.org/sites/default/files/Ulrich\%20TTake_0.pdf

Stone, R. (2020). New tensions dim hopes for salvaging Iran nuclear deal. Science, 368(6497), $1300-1301$. https://science.sciencemag.org/content/368/6497/1300.summary

Sæter, M. (1971). Det politiske Europa. Europeisk integrasjon: Teori, idé og praksis. Universitetsforlaget.

Sæter, M. (2005). USA sett fra Europa. I J. K. Skogan (Red.), Hva nå USA og Europa? (s. 33-49). Gyldendal.

Tollefson, J. (2017). Trump pulls United States out of Paris climate agreement. Nature. https:/www.nature. $\mathrm{com} /$ news/trump-pulls-united-states-out-of-paris-climate-agreement-1.22096

Tunsjø, Ø. (2018). The return of bipolarity in world politics. China, the United States and geostructural realism. Colombia University Press. 
Tvetbråten, K. \& Knutsen, B. O. (2019). Hva nå, norsk forsvarsindustri? Instrumentelle og institusjonelle svar på EUs nye politikk på det sikkerhets- og forsvarspolitiske område. Internasjonal Politikk, 77(4), 398-419. https://doi.org/10.23865/intpol.v77.1611

Van Ham, P. (2018). Trump's impact on European security. Policy options in a post-western world. Clingendael. Netherlands Institute of International Relations. https://www.clingendael.org/sites/default/files/2018-01/ Report_Trumps_Impact_on_European_Security.pdf

\section{Abstract in English \\ Why So Ambivalent? US Policies Towards the EU's Defence Ambitions}

The article discusses the relationship between the European integration process and Atlantic cooperation under US leadership. The research question the article answers is what kind of approaches the Trump Administration has had towards the EU's security and defence policies and how we can explain these approaches. More precisely, the article discusses the balances between European strategic autonomy on the one hand and American leadership in NATO on the other. This has all to do with the question of leadership in Euro-Atlantic security politics, which has been an enduring question ever since the European integrations process was initiated during the 1950's. By utilising an organisation theoretical approach, the article seeks to explain why the US approaches the EU from an instrumental point of view. Such a perspective implies that the US priorities resources to those areas in the world where the US faces its greatest challenges. To explain this development the article discusses the US' attitudes towards the EU's defence package and the superpower's ambivalence towards it. When assessing the new Biden Administration, it therefore becomes important to explain the foundation for the transatlantic security community. Such a community is not about common interests only, but also about shared norms and values on how to handle common security challenges.

Keywords: USA $\bullet$ EU $\bullet$ NATO $\bullet$ organisation theory $\bullet$ security politics 